\title{
PŘÍPRAVA ZÁKONA O PODPOŘE ROZVOJE CESTOVNÍHO RUCHU A JEHO VÝZNAM V KONTEXTU POLITIKY CESTOVNÍHO RUCHU V ČESKÉ REPUBLICE
}

\author{
RADEK CHALOUPKA
}

\begin{abstract}
Preparation of Tourism Act Development Support and its Importance in Context of the Tourism Policy in the Czech Republic

Complex tourism regulation in the form of a special act is a problem discussed in the Czech Republic for many years. The reason is current tourism regulation which from the view of implementing tourism policy poses a risk to the state that no systemic framework is formed which has high potential of causing wastefulness, ineffectiveness and uselessness of public expenditure. Key problem are vaguely adjusted competences on the level of state administration and autonomous regions that limit implementation of principles of destination management and tourism policy as the part of economic policy of the Czech Republic. Such situation prevents better use of tourism potential regardless of increasing importance of tourism for economy, in relation to developed foreign destinations, it also leads to loss in its competitiveness.

Only dealing with the basic problems can result in change of current situation. Adjustment of current tourism legislation is not sufficient solution. It means to set up a whole new tourism regulation that creates systemic framework for implementing tourism policy. For those reasons the complex tourism regulation is broadly discussed as the systemic solution.

Defence of the new regulation as the norm of administrative law with the linkages to the private law that is being seriously prepared since 2010 , is in current situation of public sector very difficult. Insufficient support of argumentation, overall low political support and divided attitude of stakeholders of the companies within the area of tourism (both public and private) led to temporary non-approval with the draft law and which has led to suspention of its processing.
\end{abstract}

Key words: tourism, tourism policy, Tourism act development support, public administration, destination management

Klíčová slova: cestovní ruch, politika cestovního ruchu, zákon o podpoře rozvoje cestovního ruchu, veřejná správa, destinační management

DOI: $10.14712 / 23366478.2016 .41$

\section{ÚVOD}

Komplexní právní úprava odvětví cestovního ruchu v podobě samostatného zákona je v České republice s různou intenzitou mnoho let otázkou diskutovanou širokou odbornou veřejností. Ministerstvo pro místní rozvoj, které je věcně př́slušným ústředním orgánem státní správy ve věcech cestovního ruchu, se doposud nepodařilo 
obhájit legitimitu jeho vytvoření. Nutno podotknout, že ani v rámci celého sektoru nebyla prozatím nalezena shoda na tom, co všechno by zcela nový zákon upravující cestovní ruch měl řešit.

Pro správné pochopení dlouholeté snahy upravit cestovní ruch v České republice v samostatném zákoně je nutné vymezit současnou právní úpravu odvětví, která vychází ze současného systému veřejné správy České republiky a vytváří tak podmínky pro rozvoj odvětví a uplatňování (formování, realizaci, kontrolu a hodnocení) politiky cestovního ruchu na úrovni státu, krajů, měst a obcí. Současně nezbývá nic jiného než se také zabývat praktickými problémy a současnou situací odvětví cestovního ruchu, které potřebu zákona u různých zainteresovaných subjektů vyvolávají.

\section{VYMEZENÍ POLITIKY CESTOVNÍHO RUCHU V ČESKÉ REPUBLICE}

Cestovní ruch je významným socioekonomickým fenoménem. V rámci národního hospodářství je odvětvím stimulujícím ekonomický rozvoj regionů s četnými multiplikačními a synergickými efekty. Tento charakter cestovního ruchu je dán zejména jeho horizontálními vazbami s celou řadou odvětví. Vzájemné působení mezi odvětvími a cestovním ruchem vyžaduje rrízení a koordinování, což vytvárí prostor pro uplatnění politiky cestovního ruchu.

Obecně lze politiku definovat jako vědomou podporu nebo správu věcí veřejných př́padně umění ř́dit stát. Politiku cestovního ruchu poté můžeme vymezit jako souhrn metod a nástrojů, kterými stát a jeho orgány (nositelé) zasahují do rozvoje cestovního ruchu v zájmu naplnění stanovených cílů ${ }^{1}$ nebo cílené, organizované plánování, ovlivňování reality a buducnosti cestovního ruchu prostřednictvím různých nositelů. ${ }^{2}$ Politika cestovního ruchu je realizována na úrovni nadnárodní, národní, regionální a př́ípadně také místní s tím, že veřejná správa a její orgány mají rozhodující úlohu při jejím vytváření a realizaci. ${ }^{3}$

Různými autory je uváděna celá řada argumentů obhajující legitimitu politiky cestovního ruchu respektive důvody intervencí veřejného sektoru do tohoto odvětví, které vycházejí z mikroekonomických a makroekonomických souvislostí. Na druhé straně se můžeme setkat i s četnou argumentací, která cestovní ruch považuje především za podnikatelský sektor, do kterého by stát měl omezit své zásahy na minimum. Odpůrci často argumentují neefektivitou veřejných intervencí a narušováním konkurenčního prostředí. ${ }^{4} \mathrm{~V}$ České republice je celková efektivita politiky cestovního ruchu kritizována. Je možné najít mnoho př́íkladů, kde zásahy ze strany státu vedly k narušení konkurenčního prostředí nebo měly charakter nehospodárně vynaložených veřejných

1 HOLEŠINSKÁ, A.: Destinační management jako nástroj regionální politiky cestovního ruchu. Doktorská disertační práce. Brno: Masarykova univerzita, Ekonomicko-správní fakulta, 2010.

2 FREYER, W.: Tourismus - Einführung in die Fremdenverkehrsökonomie. München, 2005.

3 ŠAUER, M.: Podpora cestovního ruchu z veřejných financí. Doktorská disertační práce. Brno: Masarykova univerzita, Ekonomicko-správní fakulta, 2008, a GÚČIK, M.: Cestovný ruch: politika a ekonómia. Banská Bystrica, 2011.

4 Těmito otázkami se blíže zabývá ve své disertační práci ŠAUER, M. 
prostředků. Mezi nejčastější př́íklady bývá udáváno nehospodárné využití finančních prostředků ze strukturálních fondů Evropské unie, které byly v některých př́padech využity na podporu projektů s pochybným dopadem nebo přímo narušily konkurenční prostředí cestovního ruchu.

Teorie definuje různé př́istupy k politice cestovního ruchu, nejčastěji rozlišuje politiku pragmatickou, politiku rádu, strukturální politiku, koncepčně - dogmatickou politiku nebo politiku jako normativní součást destinačního managementu. ${ }^{5} \mathrm{~V}$ České republice je nejčastěji uplatňována zejména koncepčně-dogmatická politika cestovního ruchu, která je určována koncepčními a strategickými dokumenty na různé úrovni jejich institucionálního zajištění vycházející ze systému veřejné správy. Formální legitimita politiky cestovního ruchu v takovém prrípadě vychází z platných právních předpisů.

\section{POLITIKA CESTOVNÍHO RUCHU ČESKÉ REPUBLIKY A VEŘEJNÝ SEKTOR}

Základní systémový rámec pro uplatňování politiky cestovního ruchu veřejným sektorem definuje zejména zákon č. 2/1969 Sb., o zř́zení ministerstev a jiných ústředních orgánů státní správy České republiky; zákon č. 129/2000 Sb., o krajích (krajské zrrízení); zákon č. 128/2000 Sb., o obcích (obecní zř́zení), a zákon č. 131/2000 Sb., o hlavním městě Praze. Na formování politiky cestovního ruchu má rovněž vliv celá řada speciálních právních předpisů z oblasti správního, soukromého a obchodního práva, které jednak vymezují její rámec anebo představují v podobě dalších zákonů, vyhlášek a technických norem její regulační nástroje.

Stávající legislativní prostředí stanovuje základní rozsah kompetencí vybraných subjektů veřejné správy a dává tak konkrétním institucím formální legitimitu stanovovat cíle politiky cestovního ruchu nebo ovlivňovat způsob jejího uplatňování. Jednoduše řečeno stát prostř̌ednictvím právních předpisů svěřuje různým subjektům veřejné správy mandát př́mo politiku cestovního ruchu vytvářet nebo jí alespoň významně ovlivňovat. Samotná podstata pověření vybraných institucí formováním politiky cestovního ruchu je oprávněná a vyplývá z legitimity a účelnosti zasahování státu do tohoto odvětví. Hlavní problém však spočívá v obecnosti tohoto mandátu, který definuje stávající legislativa a celkový systém veřejné správy. Konkrétní zákonná ustanovení se ve vztahu k cestovnímu ruchu omezují na jednoduchá konstatování, které dávají relativně vágní rámec institucím, které se na formování politiky cestovního ruchu podílejí.

Dle zákona č. 2/1969 Sb., o zřízení ministerstev a jiných ústředních orgánů státní správy České republiky, je ministerstvo pro místní rozvoj ústředním orgánem státní správy ve věcech cestovního ruchu. Konkrétní vymezení kompetencí včetně jednoznačné odpovědnosti za formování politiky cestovního ruchu státu $\mathrm{v}$ tomto zákonu nenajdeme. Co přesně, bude ministerstvo pro místní rozvoj ve věcech cestovního ruchu vykonávat, není v tomto zákoně přesně stanoveno. Konkrétní kompetence je ministerstvu stanovena pouze ze zákona č. 159/1999 Sb., o některých podmínkách podnikání

5 BIEGER, T.: Management von Destinationen und Tourismus Organisationen. München, 2006. 
v cestovním ruchu, který je však nástrojem politiky cestovního ruchu upravující pouze její dílčí část. Pořízení Koncepce státní politiky cestovního ruchu jako základního dokumentu politiky cestovního ruchu není nijak legislativně zakotveno, a to včetně jejich finančních a marketingových nástrojü, kterými ministerstvo disponuje. Výsledkem tak je, že ani agentura CzechTourism jako klíčová instituce, která je nositelem státní politiky cestovního ruchu a její nástrojem v oblasti propagace České republiky, není př́mo zakotvená $\mathrm{v}$ žádném právním předpisu. Obdobná situace je i v př́padě základního finančního nástroje ministerstva $\mathrm{v}$ podobě Národního programu podpory cestovního ruchu. Bližší představu o agendě ministerstva pak můžeme najít již jen $\mathrm{v}$ jeho organizačním řádu, který je však jednostranným institucionálním aktem, jehož závaznost je možné posuzovat pouze z pohledu platnosti dokumentu jako interní směrnice úřadu. Výkon agendy cestovního ruchu se tak významně odvíjí od politického vedení ministerstva a nemusí tak být $\mathrm{v}$ souladu s dlouhodobými zájmy odvětví.

Dle zákona č. 129/2000 Sb., o krajích (krajské zř́zení), je cestovní ruch svěřen do samostatné působnosti krajů, přičemž zákon stanovuje možnost zastupitelstvu schvalovat koncepce rozvoje cestovního ruchu na území kraje, zajištovat jejich realizaci a kontrolovat jejich plnění. V zákoně č. 128/2000 Sb., o obcích (obecní zř́zení), mohou obce vykonávat úkoly v oblasti cestovního ruchu v rámci spolupráce prostřednictvím svazku obcí. V zákoně č. 131/2000 Sb., o hlavním městě Praze, nalezneme obdobnou úpravu umožňující spolupráci v oblasti cestovního ruchu prostřednictvím svazku obcí a navíc v přenesené působnosti dává zákon městským částem možnost zakládat, zřizovat a rušit právnické osoby a organizační složky potřebné pro jejich rozvoj a pro uspokojování potřeb občanů městských částí možnost i v oblasti cestovního ruchu. Konkrétní vymezení činností realizovaných v samostatné působnosti krajů nebo v rámci spolupráce obcí, není v cestovním ruchu na úrovni samosprávy přesněji vymezeno a významně se odvíjí od politického vedení krajů nebo obcí. Každý kraj nebo obec si tak dle svého uvážení formuje vlastní politiku cestovního ruchu včetně jejich nástrojů a nositelů. Tento předpoklad byl ověřen i v nezávislých studiích, které potvrdily, že cestovní ruch je na samosprávné úrovni na politických rozhodnutích významně závislý. ${ }^{6}$

Současná právní úprava cestovního ruchu představuje z pohledu uplatňování politiky cestovního ruchu pro stát riziko, které již ve svém základu vytváří nesystémové prostředí s vysokým potenciálem nehospodárnosti, neefektivity a neúčelnosti veřejných výdajů. Instituce veřejného sektoru, které mají formální legitimitu pro uplatňování politiky cestovního ruchu, nejsou žádným způsobem ze strany státu zavázány ke vzájemné spolupráci a v oblasti cestovního ruchu mohou sledovat pouze své vlastní cíle. Navíc chybí nástroj jakékoliv zpětné kontroly, kterým by stát mohl účinně sledovat a vyhodnocovat politiku cestovního ruchu a kontrolovat veškeré veřejné výdaje. ${ }^{7}$

Dle studie společnosti KPMG ČR zpracované pro ministerstvo pro místní rozvoj vyplývá, že v roce 2011 bylo na podporu cestovního ruchu veřejným sektorem vynaloženo minimálně 3,8 mld. Kč. K tomu dle Zprávy o vyhodnocení Koncepce státní politiky

6 PLZÁKOVÁ, L. - STUDNIČKA, P. - VRCHOTOVÁ, M.: Organizace cestovního ruchu v krajich a turistických regionech České republiky. Praha, 2012.

7 Nejvyšší kontrolní úřad jako kontrolní orgán má pravomoc kontrolovat veřejné výdaje poskytované státní správou (včetně evropských fondů), nikoliv výdaje poskytované samosprávou. 
cestovního ruchu ministerstva pro místní rozvoj bylo v letech 2007-2014 ze strukturálních fondů EU do cestovního ruchu investováno průměrně 7 mld. Kč ročně. Rozhodně nelze označit tyto veřejné prostředky jako marginální a umožnit, aby byly vynakládány v takto rizikovém prostředí, ve kterém je politika cestovního ruchu více závislá na politickém rozhodování, dílčích zájmech, než na koncepčním přístupu.

I přes nesystémový přístup veřejného sektoru cestovní ruch v České republice dosahuje relativně dobré výkonnosti se stále rostoucím významem pro ekonomiku. Dle posledních údajů se podílel $2,9 \%$ na HDP, 4,55 \% na celkové zaměstnanosti ${ }^{8}$ a do veřejných rozpočtu na daních přnáší průměrně 93 mld. Kč ročně. ${ }^{9}$ Tato výkonnost je do jisté míry daná také tím, že cestovní ruch je dlouhodobě globálně rostoucím odvětvím, Česká republika disponuje kvalitními výchozími lokalizačními předpoklady a trh cestovního ruchu je tvořen subjekty, které se flexibilně naučily přizpůsobovat a reagovat na změny tržní situace. Měřítkem výkonnosti České republiky, by však nemělo být vlastní uspokojení z dosahovaných výsledků, ale porovnávání výkonnosti českého cestovního ruchu s jinými odvětvími národního hospodářství a s nejbližšími konkurenty. $\mathrm{V}$ tomto srovnání je pozice cestovního ruchu o poznání horší, nebot' dlouhodobě jeho podíl na HDP spíše stagnuje ${ }^{10}$, přičemž ani často používané mezinárodní srovnání s Rakouskem a Švýcarskem nevyznívá pro Českou republiku dobře. ${ }^{11}$ Můžeme najít mnoho př́kladů z jiných odvětví, ve kterých byla počáteční konkurenční výhoda vyčerpána a není důvod si myslet, že stejná situace nemůže nastat i v cestovním ruchu. Ze strany veřejného sektoru je poněkud riskantní přistupovat takto nesystémově k odvětví, které disponuje tak vysokým potenciálem a předpoklady k celkové výkonnosti.

\section{POLITIKA CESTOVNÍHO RUCHU JAKO INTEGRÁLNÍ SOUČÁST HOSPODÁŘSKÉ POLITIKY}

Politika cestovního ruchu je také definována jako integrální součást hospodářské politiky státu. ${ }^{12}$ Není proto možné na ní nahlížet izolovaně prostřednictvím institucí, které mají k jejímu uplatňování formální legitimitu. Na politiku cestovního ruchu mají totiž také vliv rozhodnutí institucí, kterým rozvoj cestovního ruchu nebyl př́mo svěřen do kompetence, což vede k tomu, že se fakticky i ty stávají její součástí. Teorie cestovního ruchu takové instituce označuje jako její nositele, přičemž s ohledem na provázanost cestovního ruchu v rámci hospodářské politiky se jedná o většinu z nich. Přestože Koncepce státní politiky cestovního ruchu společné cíle stanovuje alespoň

8 Satelitní účet cestovního ruchu, Český statistický úřad, poslední známé oficiální údaje za rok 2013.

9 Průměrné př́nosy za období 2006-2011, Studie společnosti KPMG ČR zpracované pro ministerstvo pro místní rozvoj.

10 Dle Satelitního účtu cestovního ruchu od roku 2003 klesl podíl na HDP z 3,5 na 2,9 \% v roce 2013 (předběžná data).

11 Porovnání výkonnosti lze demonstrovat např. prostřednictvím Indexu mezinárodní konkurenceschopnosti cestovního ruchu, ve kterém Německo, Švýcarsko a Rakousko v roce 2015 figuruji na 3., 6., 12. místě na rozdíl od České republiky, která je 37.

12 METELKOVÁ, P.: Pragmatická politika cestovního ruchu na prríkladu Švýcarska. In IX. Mezinárodní kolokvium o regionálních vědách. Brno, 2006, od s. 221-228. 
na úrovni státních institucí, v jejím praktickém uplatňování, jsou její reálné výsledky obtížně prokazatelné, nebot' horizontální koordinace funguje jen omezeně a vertikální koordinace nefunguje téměř vůbec. ${ }^{13}$ Najít můžeme mnoho př́kladů, kdy rozhodnutí ústředních orgánů státní správy, ale i četná rozhodnutí na úrovni samosprávy měla na odvětví cestovního ruchu významné dopady, aniž by byla součástí jakékoliv koncepce nebo byla z pohledu dopadů na cestovní ruch odpovědně posouzena. Aktuálním př́íkladem s významným dopadem na cestovní ruch může být rozhodnutí České národní banky dlouhodobě působit na oslabení hodnoty české koruny. Ačkoliv dopady tohoto opatření na cestovní ruch nebyly prozatím blíže zkoumány, je možné z povahy cestovního ruchu jako exportního odvětví předpokládat, že budou celkově pozitivní. Nicméně k žádnému serióznímu posouzení z pohledu politiky cestovního ruchu nedošlo.

Stát by tak měl prostřednictvím svých institucí vytvořit prostředí, které umožní uplatňovat politiku cestovního ruchu systémovým způsobem. Na politiku cestovního ruchu jako na integrální součást hospodářské politiky bychom proto měli nahlížet jako na jeden celek, který směřuje k celkové institucionální schopnosti veřejné správy vytvářet prostředí pro její uplatňování. Celková schopnost veřejné správy institucionálně naplňovat stanové cíle v oblasti cestovního ruchu by pak měla být měřítkem její efektivity. Tento předpoklad neznamená její formulování prostřednictvím jednoho koncepčního dokumentu, ve kterém budou stanoveny shodné cíle, nýbrž prostředí pro uplatňování politiky cestovního ruchu musí zajistit její jednotné směřování včetně požadavků na provázání dílčích koncepcí a společnou koordinaci jejich nástrojů a nositelů. Současně by také měla být dosažena rovnováha mezi požadavky na politiku cestovního ruchu a legitimními zájmy jednotlivých veřejných institucí.

\section{POLITIKA CESTOVNÍHO RUCHU JAKO SOUČÁST DESTINAČNÍHO MANAGEMENTU}

Politika cestovního ruchu v České republice však není jen věcí veřejného sektoru. Jako normativní součást destinačního managementu ${ }^{14}$ jí významně uplatňují zejména organizace destinačního managementu, jejichž cílem je zajišt'ovat kooperaci a koordinaci subjektů cestovního ruchu v destinaci. Výsledkem činnosti destinačního managementu by mělo být vybudování atraktivních destinací cestovního ruchu jako základu konkurenceschopnosti odvětví cestovního ruchu. Funkční destinační společnosti by měly mít vazbu na území a jeho potenciál a vycházet ze spolupráce soukromých, neziskových a veřejných subjektů, které zde působí.

13 Horizontální koordinací politiky cestovního ruchu je myšlena její koordinace na úrovni státní správy. Vertikální koordinací potom její koordinace mezi státní správou a samosprávou.

14 Destinační management, neboli řízení destinace, lze definovat jako specifickou formu řízení, která spočívá $\mathrm{v}$ procesu založeném na kooperaci (spolupráci) mezi jednotlivými zainteresovanými aktéry cestovního ruchu a na koordinaci v oblasti plánování, organizování a rozhodování v destinaci, přičemž klíčovým faktorem úspěšné realizace destinačního řízení je vzájemná komunikace: HOLEŠINSKÁ, A.: Destinační management jako nástroj regionální politiky cestovního ruchu. Doktorská disertační práce. Brno: Masarykova univerzita, Ekonomicko-správní fakulta, 2010. 
Organizace destinačního managementu jsou však v České republice na rozdíl od Rakouska, Švýcarska a jiných turisticky vyspělých zemích zakládány spíše institucionálním rozhodnutím veřejného sektoru, kterým jsou také financovány. Stávají se tak mnohdy nástrojem pro uplatňování zájmů veřejného sektoru, než funkčními společnostmi, jejichž cílem je budování atraktivity a konkurenceschopnosti destinací. Tyto organizace často nemají přirozenou vazbu na předpoklady a potenciál území nebo nefungují jako skutečná platforma pro spolupráci subjektů v destinaci. Př́istup veřejného sektoru a stávající institucionální prostředí politiky cestovního ruchu tak omezují uplatňování principů destinačního managementu, ačkoliv by mělo být jejím základem. Podnikatelské subjekty, které se mají stát přirozeným iniciátorem tohoto př́stupu, nemají důvod vznik organizací destinačního managementu iniciovat a financovat. Do neefektivního prostředí, kde dochází k narušování konkurenčního prostředí a nesystémovým zásahům ze strany veřejného sektoru, žádný podnikatel své prostředky nevloží. Jedním ze základních cílů veřejného sektoru by tak mělo být odstranění těchto příčin a vytvoření prostředí, které bude zejména podnikatelské subjekty k financování a rozvoji organizací destinačního managementu motivovat.

\section{ZÁKON O PODPǑ̌E ROZVOJE CESTOVNÍHO RUCHU JAKO SYSTÉMOVÝ NÁSTROJ POLITIKY CESTOVNÍHO RUCHU V ČESKÉ REPUBLICE}

Dobrovolné koordinační nástroje svůj účel neplní. Zachování současné právní úpravy cestovního ruchu tak není řešením a oprávněně bývá označováno za př́činu vzniku nesystémového prostředí s vysokým rizikem neefektivity. Odstranění príčin může přinést pouze změna stávajícího stavu tak, aby nová právní úprava vytvořila alespoň základní systémový rámec pro uplatňování politiky cestovního ruchu.

V praxi je obtížně představitelné, že pouze novelizace stávajících právních předpisů může být dostatečná. ${ }^{15}$ Jen do těchto právních předpisů totiž není možné zahrnout požadavky, které vyžaduje vytvoření systémového prostředí pro uplatňování politiky cestovního ruchu. Jednoduché řešení stávající situace např. odebráním kompetencí cestovního ruchu z úrovně státní správy nebo samosprávy, je nejen politicky obtížně proveditelné, ale ani není v souladu s požadavkem na vytvoření systému.

Úprava cestovního ruchu prostřednictvím samostatného zákona jako nástroje pro zajištění systémového prostředí politiky cestovního ruchu je koncepčním řešením, které je zakotveno v aktuální platné Koncepci státní politiky cestovního ruchu ČR na období 2014-2020. ${ }^{16}$ Zároveň je to řešení legitimní, nebot' umožňuje efektivněji usměrňovat politiku cestovního ruchu a vede $\mathrm{k}$ hospodárnějšímu vynakládání veřejných prostředků a umožňuje vytvořit podmínky pro uplatňování principů destinačního managementu.

15 Zákon č. 2/1969 Sb., o zř́zení ministerstev a jiných ústředních orgánů státní správy České republiky; zákon č. 129/2000 Sb., o krajích (krajské zřízení); zákon č. 128/2000 Sb., o obcích (obecní zřízení), a zákon č. 131/2000 Sb., o hlavním městě Praze.

16 Schváleno vládou usnesením č. 220 ze dne 27. března 2013. 
Zákon o podpoře cestovního ruchu je normou správního práva a jako takový se musí vyrovnat se současným stavem veřejné správy, který je katastrofální. ${ }^{17}$ Zřejmě i tato situace přispěla $\mathrm{k}$ tomu, že přestože se zákon o podpoře rozvoje cestovního ruchu seriózně připravuje již od roku 2010, nepodařilo se ministerstvu pro místní rozvoj jeho význam doposud obhájit. Dosavadním maximem bylo projednávání věcného záměru zákona, které však vždy skončilo v legislativním procesu ještě před předložením do vlády. ${ }^{18}$ Výsledkem bylo, že po téměř 5 letech práce ministerstvo pro místní rozvoj stáhlo předložení věcného záměru zákona z plánu legislativních úkolů vlády, což znamená faktické zastavení jeho další príípravy.

Návrh zákona o podpoře rozvoje cestovního ruchu jako řešení navrhoval vytvoření třístupňové organizační struktury cestovního ruchu na úrovni stát, kraj, turistická oblast. Vedle institucionálního provázání veřejné správy v oblasti cestovního ruchu bylo jeho součástí uplatňování principů destinačního managementu na všech úrovních nově vytvořené organizační struktury. ${ }^{19}$ Součástí návrhu byl systém financování, který měl zajistit adresnou alokaci veřejných prostředků a iniciovat financování zejména organizací destinačního managementu ze soukromých zdrojů.

\section{KLÍČOVÉ ARGUMENTY PROTI ZÁKONU O PODPOŘE ROZVOJE CESTOVNÍM RUCHU}

Připomínek proti připravenému věcnému záměru zákona zejména ze strany legislativní rady vlády, ministerstva financí a ministerstva vnitra, bylo několik, včetně zpochybňování jeho podstaty samotné. Ty zásadní spočívaly v následujících argumentech:

- zákon nemůže upravovat politiku cestovního ruchu;

- zákonem nelze nařídit spolupráci subjektů cestovního ruchu;

- zákonem nelze nařídit krajům a obcím výkon určitých aktivit $\mathrm{v}$ rámci politiky cestovního ruchu, nebot' tato spadá do jejich samostatné působnosti;

- organizace destinačního managementu na třetí úrovni ř́zení jsou soukromoprávní subjekty, přičemž stát není jejich zakladatel ani zrrizovatel, a proto nemůže zasahovat do jejich činnosti;

- zákon nemůže upravovat financování organizací destinačního managementu, nebot' by to znamenalo zavádění mandatorních výdajů, přičemž financování rozvoje cestovního ruchu na principu sdruženého financování (veřejný sektor, podnikatele) by $v$ podstatě znamenalo vytvoření fondu cestovního ruchu.

Obecně lze k připomínkám uvést, že některé z nich mají charakter nepochopení účelů zákona, možná způsobené nedostatečnou či nesprávnou argumentací na jeho

17 PETRÁS̆, R.: Právo a cestovní ruch. Praha, 2013, s. 161.

18 Ministerstvo pro místní rozvoj předložilo do legislativního procesu dvě verze věcného záměru zákona první v roce 2011 a druhou přepracovanou $v$ roce 2013.

19 Připravovaný zákon definoval činnost organizací destinačního managementu na úrovni státní správy (CzechTourism), samosprávy (krajské destinační společnosti) a na úrovni turistických oblastí. 
podporu. Jiné připomínky jsou spíše výsledkem nedostatečné politické podpory zákon prosadit a neochoty spolupracovat.

Zákon totiž skutečně nemůže upravovat politiku cestovního ruchu, a to alespoň ve smyslu požadavků na její obsah. Cílem zákona musí být vytvoření právního rámce / prostředí pro její uplatňování (formování, realizaci, kontrolu a hodnocení). Zákon je v tomto smyslu nástrojem politiky cestovního ruchu, nikoliv jejím tvůrcem, nebot' ta musí i nadále zůstat $\mathrm{v}$ odpovědnosti legitimních subjektů. Ve vztahu ke spolupráci platí obdobný princip, nebot žádný zákon tohoto dosáhnout nemůže. Cílem zákona může být její usměrňování tak, aby se tato spolupráce odehrávala $\mathrm{v}$ souladu s vytvořeným rámcem pro uplatňování politiky cestovního ruchu. Právní rámec vytvořený zákonem by měl spolupráci subjektů cestovního ruchu podněcovat, nikoliv jí díky současné právní úpravě omezovat.

Mezi jednu z klíčových připomínek patří argument, že zákon zasahuje do samostatné působnosti krajů a obcí, nebot' určuje co je předmětem jejich činnosti. Tato připomínka je sice pravdivá, ale platí pouze za stávající právní úpravy cestovního ruchu, která se stala prŕíčinou problémů. Jak bylo uvedeno výše, vágně nastavená legitimita pro uplatňování politiky cestovního ruchu subjektům veřejného sektoru vytváŕí nesystémové a vysoce rizikové prostředí s potenciálem nehospodárně vynakládaných veřejných prostředků. Ve veřejném sektoru nalezneme mnoho př́kladů, kdy stát do samostatné působnosti krajů zasahuje. ${ }^{20}$ Činí tak nejen v souladu se stávající právní úpravou, ale především ve veřejném zájmu, za účelem kvalitnějšího výkonu veřejné správy a hospodárně vynakládaným veřejným prostředkům. Bohužel díky dlouhotrvajícímu stávajícímu stavu se dohoda na vymezení činností cestovního ruchu mezi státní správou a samosprávou hledá obtížně. Zejména kraje se od jejich vzniku v roce 2000 v cestovním ruchu etablovaly natolik, že každý z nich si legitimně vede svou politiku cestovního ruchu, což nalezení univerzálního řešení komplikuje. Právě nejednota mezi představiteli ministerstva pro místní rozvoj a krajů při řešení procesních požadavků zákona a vymezení odpovědností byla jedním $\mathrm{z}$ důsledků jeho odmítnutí.

Zásadní připomínky se vztahovaly také k vymezení třetí úrovně organizační struktury na úrovni turistických oblastí. Problematické již je vymezení právní formy organizací destinačního managementu, jejich vymezení v území a jejich vazby na podnikatelský sektor. Zákon, který je především normou správního práva se tím také dostává do roviny práva soukromého. $V$ návrhu zákona byly stanoveny vhodné právní formy a kritéria, na jejichž základě mohly tyto organizace vznikat či se do nich transformovat. Stanovení pravidel pro organizace destinačního managementu bylo důležité zejména $z$ důvodu jejich vazby na území a možnostem poskytování finanční podpory ze strany veřejného sektoru (stát, kraje, obce). Tím by byla odstraněna současná neefektivita v distribuci veřejných výdajů a zároveň by bylo umožněno tyto prostředky nasměrovat organizacím, které jsou schopné získávat soukromé zdroje. Ačkoliv zasahování do činnosti soukromoprávních subjektů patřilo mezi hlavní připomínky, tak výsledkem mělo být pouze vytvoření rámce, kterým bude veřejný sektor iniciovat podporu cestovního ruchu prostřednictvím principu destinačního managementu. Je celkem běžné v různých odvětvích

20 Např. památková péče, stavební řád, územní plánování. 
národního hospodářství, že veřejný sektor definuje pravidla pro soukromý sektor, který je na jejich základě oprávněn čerpat finanční podporu. ${ }^{21}$ Podpora organizací destinačního managementu $\mathrm{z}$ veřejných zdrojů sice vyžaduje nastavení nových finančních toků, nicméně nemá podstatný vliv z pohledu celkových výdajủ veřejného sektoru na cestovní ruch, nebot' zákonem mělo dojít zejména k hospodárnějšímu využivání současně poskytovaných veřejných zdrojů.

\section{ZÁVĚR}

Prozatímní neschválení ani věcného návrhu zákona byl do jisté míry předvídatelný výsledek, a to nejen $z$ důvodu nedostatečné argumentace a schopnosti ministerstva vypořádat zásadní připomínky, ale zejména díky celkově nízké politické podpoře záměru a nejednotnému př́stupu aktérů cestovního ruchu (veřejných i soukromých). Především rozdílné postoje aktérů cestovního ruchu, kteří mnohdy upřednostňovali své dílčí zájmy na úkor komplexního a systémového řešení, byly významnou př́ičinou výsledného stavu.

Přestože je posuzování reálných výsledků politiky cestovního ruchu velmi obtížné, ${ }^{22}$ mělo by být snahou ze strany veřejného sektoru vytvářet pro uplatňování politiky cestovního ruchu stále kvalitnější prostředí, ve kterém bude odpovědně využiván a rozvíjen potenciál cestovního ruchu a nebude docházet $\mathrm{k}$ neefektivně vynakládaným veřejným prostředkủm. Na politiku cestovního ruchu je potřeba nahlížet jako na systém, u kterého také platí, že jeho celková výkonnost bude taková, jako je jeho nejslabší část. Veřejný sektor, který sehrává v politice cestovního ruchu jednu z klíčových rolí, tak může změnou současné právní úpravy cestovního ruchu dát tomuto odvětví důležitý rozvojový impuls a nebýt jeho slabým článkem.

Ing. Radek Chaloupka

Vysoká škola ekonomická

r_chaloupka@volny.cz

21 V souladu s platnými nařízeními EK definující problematiku nedovolené veřejné podpory - Nařízení Komise č. 651/2014 ze dne 17. června 2014.

22 ŠAUER, M.: Podpora cestovního ruchu z veřejných financí. Doktorská disertační práce. Brno: Masarykova univerzita, Ekonomicko-správní fakulta, 2008. 